\title{
Effect of fertilization with fluid swine slurry on production and nutritive value of Tifton 85
}

\author{
Hernan Vielmo ${ }^{1}$, Amadeu Bona Filho ${ }^{2}$, André Brugnara Soares ${ }^{3}$, Tangriani Simioni \\ Assmann ${ }^{3}$, Paulo Fernando Adami ${ }^{3}$ \\ 1 Universidade Tecnológica Federal do Paraná - Campus Francisco Beltrão. \\ 2 Universidade Federal do Paraná - UFPR. \\ 3 Universidade Tecnológica Federal do Paraná - Campus Pato Branco.
}

\begin{abstract}
The objective of this study was to evaluate the effect of different doses of liquid swine slurry on dry matter accumulation rate and nutritive values (crude proten and neutral detergent fiber) of Tifton 85 grass pasture cultivated in southwestern Paraná from October 2005 to March 2006. It was used a complete random experimental design in a $4 \times 4$ factorial scheme composed of four doses of swine slurry in the plots $\left(0,80,160\right.$ and $320 \mathrm{~m}^{3} / \mathrm{ha}$ ) and four consecutive cuts in the subplots of the pasture. It was carried out two applications, one in the beginning of the experiment and other after 80 days. Cuts were performed every time pasture height was $40 \mathrm{~cm}$. There was a dose versus cut interaction for all variables. Swine slurry promoted increase on dry matter accumulation rate only on the first cut after its application (cuts 1 and 3). Dry matter maximal yield (24.2 t/ha) was obtained at $249 \mathrm{~m}^{3} / \mathrm{ha}$ of swine slurry manure (143 and $106 \mathrm{~m}^{3} / \mathrm{ha}$, respectively for applications 1 and 2), corresponding to $450 \mathrm{~kg}$ of N/ha. Percentage of crude protein increases and neutral detergent fiber of Tifton 85 grass decreases as dose of swine slurry increases, improving forage nutritive value. Use efficiency and nitrogen recovery rate decrease with addition of swine slurry doses.
\end{abstract}

Key Words: Cynodon spp., crude protein, dry matter production, neutral detergent fiber, nitrogen recovery, nitrogen use efficiency

\section{Efeito da fertilização com esterco líquido de suínos sobre a produção e o valor nutritivo do capim-tifton 85}

RESUMO - Objetivou-se avaliar o efeito de diferentes doses de dejeto líquido de suínos sobre a taxa de acúmulo de matéria seca e o valor nutritivo (proteína bruta e fibra em detergente neutro) de uma pastagem de capim-tifton 85 cultivada na região sudoeste do Paraná no período de outubro de 2005 a março de 2006. Utilizou-se delineamento experimental de blocos ao acaso em esquema fatorial de $4 \times 4$, composto por quatro doses de dejetos líquidos de suínos nas parcelas $\left(0,80,160\right.$ e $\left.320 \mathrm{~m}^{3} / \mathrm{ha}\right)$ e quatro cortes consecutivos nas subparcelas da pastagem. Foram realizadas duas aplicações, uma no início do experimento e outra 80 dias após. Os cortes foram realizados sempre que a altura da pastagem atingisse $40 \mathrm{~cm}$. Houve interação dose versus corte para todas as variáveis. Os dejetos promoveram aumento na taxa de acúmulo de matéria seca somente no primeiro corte após sua aplicação (cortes 1 e 3). O rendimento máximo de matéria seca (24,2 t/ha) foi obtido na dose de $249 \mathrm{~m}^{3} / \mathrm{ha}$ de dejetos (143 e $106 \mathrm{~m}^{3} / \mathrm{ha}$, respectivamente, para as aplicações 1 e 2), correspondentes a $450 \mathrm{~kg} / \mathrm{ha}$ de nitrogênio. O percentual de proteína bruta aumenta e o de fibra em detergente neutro do capim-tifton 85 diminui com o aumento da dose de dejetos, melhorando o valor nutritivo da forragem. A eficiência de utilização e a taxa de recuperação do nitrogênio diminuem com o incremento da dose de dejetos líquido de suínos.

Palavras-chave: Cynodon spp, eficiência de utilização do nitrogênio, fibra em detergente neutro, produção de matéria seca, proteína bruta, recuperação de nitrogênio

\section{Introduction}

The Brazilian swine production has about 32.5 million pigs, with an annual meat production of 9,749 million of tons which produces 537,5 million of tons of dejects, which are an important component of the production system inasmuch as it can be used as an agriculture input, creating a synergism among the links of the productive chain (Konzen, 2007).

Its importance is due to the great number of producers involved in the production chain and by the jobs derived from this activity, besides the great animal protein production in a small area and in a short period of time (Assis \& Muratori, 2007). However, swine production, by 
its characteristics, is known as a pollutant activity and because of this, studies on swine slurry management, especially on the used levels, need to be done (Monteiro et al., 2010).

When it is used as a fertilizer and it is well managed, swine residue represents an excellent source of nutrients, especially nitrogen, phosphorous and potassium, which can replace totally or partially the chemical fertilizer. It is also considered as an input of low cost with high income return for the agriculture producer (Menezes et al., 2007).

Among many factors, Alvim et al. (1999) and Pelegrini et al. (2010) emphasized that the nitrogen fertilization is important to determine the growing rate and nutritive value of forage grasses. On the other hand, this element is pointed as an element of great pollutant potential because its mineral form is very movable in the soil (Basso et al., 2005).

The use of animal residues as a fertilizer source is something common in annual crops, while its use on pasture has been increasing lately. Thus, hybrids from the genera Cynodon, especially the hybrid Tifton 85, have been used as an important alternative of forage specie to feed ruminants, which is rather required in soil fertility and depends on nutrient reposition to maintain high productive levels (Pedreira et al., 1998). This pasture has shown good results when fertilized with swine residue, responding with a dry matter production up to 400 (Rocha et al., 2002) and $450 \mathrm{~kg}$ of N/ha (Adeli et al., 2005). Values above these numbers are not very interesting in terms of production increase.

Related to the previous information and due to it, the aim of this work was to find the swine level at which the maximum technical efficiency, in terms of dry matter accumulation, occurs and its effect on the Tifton 85 tissue nutritive value, as well as to verify the nitrogen recovery and use efficiency.

\section{Material and Methods}

The experiment was carried out at the Universidade Tecnológica Federal do Paraná, southwest of Parana State - Brazil, from October $18^{\text {th }} 2005$ to March 21 2006. According to the Köppen classification (Maak, 1968), the climate in the region is subtropical humid, with warm summers and cold winter (frequently frosts), with an average annual maximal temperature of $25.2^{\circ} \mathrm{C}$ and minimal of $14.7^{\circ} \mathrm{C}$ and an average monthly rainfall of $177 \mathrm{~mm}$.

The soil in the experimental site is classified as an Oxisol and at the beginning of the experiment the values found in the soil analyses were: $\mathrm{pH}=5.2 ; \mathrm{P}=3.8 \mathrm{mg} / \mathrm{dm}^{3}$; $\mathrm{K}=0.6 \mathrm{Cmol}_{\mathrm{c}} / \mathrm{dm}^{3} ; 42.1 \mathrm{~g} / \mathrm{dm}^{3}$ of organic matter; $\mathrm{Ca}=$ $5.1 \mathrm{Cmol}_{\mathrm{c}} / \mathrm{dm}^{3} ; \mathrm{Mg}=3.3 \mathrm{Cmol}_{\mathrm{C}} / \mathrm{dm}^{3} ; \mathrm{H}+\mathrm{Al}=5.0 \mathrm{Cmol}_{\mathrm{C}} / \mathrm{dm}^{3}$;
CEC atpH 7.0 $=14 \mathrm{Cmol}_{\mathrm{C}} / \mathrm{dm}^{3} ;$ CEC effective $=9.2 \mathrm{Cmol}_{\mathrm{C}} / \mathrm{dm}^{3}$, $63.4 \%$ of base saturation and $\mathrm{Al}$ saturation $=0.0 \%$.

The experiment design used was a random block in a $4 \times 4$ factorial scheme composed of four swine slurry levels $\left(0,80,160\right.$ and $\left.320 \mathrm{~m}^{3} / \mathrm{ha}\right)$ and four consecutive cuts in the subplots of the pasture. There were two applications, dividing the total in two equal parts, the first one applied at the beginning of the experiment (10/18/2005) and the second one 80 days after (1/6/2006). The cuts were done consecutively on the pasture by the moment that its sward height reached $40 \mathrm{~cm}$.

The dependent variables were: dry matter accumulation rate (DMA, kg/ha/day), total dry matter production over the experimental period (TDM, kg/ha), crude protein (\%) and neutral detergent fiber (\%). The species used was Tifton 85 (Cynodon sp.), at four years of establishment. Also, from the rainfall and temperature data measured over the experimental period, the water balance was determined (Figura 1) according to Rolin et al. (1998).

Swine slurry residue was obtained from a manure pit at the Setor de Suinocultura of the Universidade Tecnológica Federal do Paraná, Dois Vizinhos, Paraná, and the application process used was the same for both applications. Swine residue was taken from the manure pit using mechanical equipment. Firstly, the manure was homogenized and later, transferred to a tank to be carried to the experimental site, where it was manually distributed using a 20-L irrigation container.

The collected manure samples were chemically analyzed at the Laboratório de Análise Química de Solos of the Universidade Tecnológica Federal do Paraná, Campus Pato Branco. Total nitrogen content and ammoniacal N $\left(\mathrm{N}-\mathrm{NH}_{4}{ }^{+}\right)$, $\mathrm{pH}$ analyses and also the total phosphorous and potassium content were determined from a fresh slurry sample (liquid + solid fraction), using a sample equal or similar to the one applied to the soil. The sample was separated in liquid and solid fractions to determine its total nitrogen content and

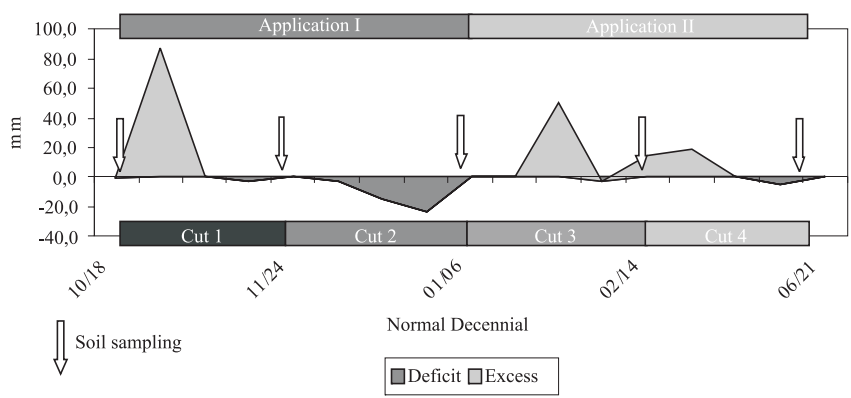

Figure 1 - Water balance (Rolin et al., 1998), normal decennial of the experimental period - October $18^{\text {th }} 2005$ to March $21^{\text {st }} 2006$. 
ammoniacal content, following the technique proposed by Scherer et al. (1996).

During the analyses, approximately $50 \mathrm{~g}$ of the manure was centrifuged for 20 minutes at 2,500 rpm, obtaining the liquid and solid fractions. This procedure was necessary to calculate the proportion of both fractions which were observed during the samples weighting for the evaluation of $\mathrm{N}$ levels, therefore reconstituting both fractions originally present in the swine manure. The ammoniacal nitrogen $\left(\mathrm{N}-\mathrm{NH}_{4}{ }^{+}\right)$from the swine slurry was determined after weighting the sample, and adding $20 \mathrm{~mL}$ of KCL $1 \mathrm{M}$ and $0.2 \mathrm{~g}$ of MgO with posterior distillation by the microKjeldahl digestion (Tedesco et al., 1995) (Table 1).

From the swine slurry dry matter and nutrient concentration, it was established the nutrients applied ( $\mathrm{kg} / \mathrm{ha})$ in each swine slurry level for each application (Table 1). The swine slurry dry matter content multiplied by the used levels determined the slurry dry matter content applied in the field (Table 2).

The evaluation of the different swine slurry levels effect over the forage dry matter production was done by cutting the aerial parts of the plants in each plot, always when the sward height of the plants was $40 \mathrm{~cm}$. Forage

Table 1 - Composition of swine slurry

\begin{tabular}{|c|c|c|}
\hline & $1^{\text {st }}$ application & $2^{\text {nd }}$ application \\
\hline Dry matter (\%) & 1.89 & 1.45 \\
\hline Total nitrogen $\left(\mathrm{kg} / \mathrm{m}^{3}\right)$ & 2.03 & 1.57 \\
\hline Mineral nitrogen $\left(\mathrm{kg} / \mathrm{m}^{3}\right)$ & 1.36 & 1.07 \\
\hline Organic-nitrogen $\left(\mathrm{kg} / \mathrm{m}^{3}\right)$ & 0.67 & 0.50 \\
\hline Total- $\mathrm{P}_{2} \mathrm{O}_{5}\left(\mathrm{~kg} / \mathrm{m}^{3}\right)$ & 1.51 & 1.05 \\
\hline Total- $\mathrm{K}_{2} \mathrm{O}\left(\mathrm{kg} / \mathrm{m}^{3}\right)$ & 1.20 & 1.00 \\
\hline
\end{tabular}

Table 2 - Nutrient content from swine slurry levels applied at the $1^{\text {st }}$ and $2^{\text {nd }}$ application over the Tifton 85

\begin{tabular}{|c|c|c|c|}
\hline & $1^{\text {st }}$ application & $2^{\text {nd }}$ application & Total \\
\hline \multirow[t]{3}{*}{ Level $\left(\mathrm{m}^{3}\right)$} & 40 & 40 & 80 \\
\hline & 80 & 80 & 160 \\
\hline & 160 & 160 & 320 \\
\hline \multirow[t]{3}{*}{ Total nitrogen $(\mathrm{kg} / \mathrm{ha})$} & 81.2 & 62.8 & 144 \\
\hline & 162.4 & 125.6 & 288 \\
\hline & 324.8 & 251.2 & 576 \\
\hline \multirow[t]{3}{*}{ Mineral nitrogen $(\mathrm{kg} / \mathrm{ha})$} & 54.4 & 42.8 & 97.2 \\
\hline & 108.8 & 85.6 & 194.4 \\
\hline & 217.6 & 171.2 & 388.8 \\
\hline \multirow[t]{3}{*}{ Organic-nitrogen $(\mathrm{kg} / \mathrm{ha})$} & 26.8 & 26.8 & 53.6 \\
\hline & 53.6 & 53.6 & 107.2 \\
\hline & 107.2 & 107.2 & 214.4 \\
\hline \multirow[t]{3}{*}{ Total- $\mathrm{P}_{2} \mathrm{O}_{5}(\mathrm{~kg} / \mathrm{ha})$} & 60.4 & 42.0 & 102.4 \\
\hline & 120.8 & 84.0 & 204.8 \\
\hline & 241.6 & 168.0 & 409.6 \\
\hline \multirow[t]{3}{*}{ Total- $\mathrm{K}_{2} \mathrm{O}(\mathrm{kg} / \mathrm{ha})$} & 48.0 & 40.0 & 88 \\
\hline & 96.0 & 80.0 & 176 \\
\hline & 192.0 & 160.0 & 352 \\
\hline
\end{tabular}

production was determined by harvesting two samples at $62.5 \mathrm{~cm}$ long $\times 40 \mathrm{~cm}$ width at $10 \mathrm{~cm}$ of height from each plot, and their averages per plot were used for statistical analyses. After sampling, the plot was rubbed at the same height which it was cut $(10 \mathrm{~cm})$.

Measurements of the plants height were done by using a sward stick, considering the distance from the soil level until the touch of the stick marker in the first leaf, measuring several sites in each plot. When the sward height average from the four replications was $40 \mathrm{~cm}$, the grass in the treatment plot was cut. The evaluations were done over the pasture cycle. Four cuttings were harvested during the experimental period (two at every slurry application) being the period between two cuts the difference, in days, from the $1^{\text {st }}$ to the $2^{\text {nd }}$ cut.

After cuts were performed, the samples were placed in identified paper bags and the green forage mass was weighted on a 1-g precision scale at the laboratory. After weighting, the samples were dried in a forced-air oven $\left(55^{\circ} \mathrm{C}\right)$ for 72 hours and weighted again to obtain the dry matter partially dried weight. The total dry matter was obtained after drying the samples in a forced-air oven at $105^{\circ} \mathrm{C}$.

A portion of the partially dried dry matter sample was milled to pass through a $<0.4-\mathrm{mm}$ screen and analyzed for crude protein content (CP) and neutral detergent fiber (NDF) by the NIRS technique described by Marten et al. (1985). The percentage of the total nitrogen in the samples was determined by dividing the crude protein by a 6.25 factor.

Considering that the number of days between the forage cuts differed in relation to the swine slurry levels and aiming at minimizing this possible effect over this variable, the accumulation rate by cut (DMA) was adjusted to the dry matter accumulation rate. The same was determined by the following formula:

$$
D M A=\frac{Q P}{\text { Days }}
$$

in which, dry matter accumulate rate (DMA) = daily dry matter accumulate variable at the cut ( $\mathrm{kg} / \mathrm{ha} / \mathrm{day}) ; \mathrm{QP}=$ the quantity of produced units from the variable at the cut, and Days $=$ the number of days to produce the quantity of units of variable units.

Nitrogen use efficiency, which determines the quantity of dry matter $(\mathrm{kg})$ produced for every kilogram of $\mathrm{N}$ applied, was determined through the dry matter production difference between the treatment using swine slurry and the treatment without swine slurry. These values were divided by the $\mathrm{N}$ quantity present in each treatment, so the nitrogen efficiency of use was found. 
For nitrogen recovery (NR) calculus, which determines the percentage of the applied $\mathrm{N}$ that was recovered (accumulate) by the plants, nitrogen production in the treatments with nitrogen (total forage production $\times$ average nitrogen content) was subtracted by the nitrogen production of the control divided by the $\mathrm{N}$ level of swine slurry levels.

The main factor used in this experiment to perform the cuts, was the sward height $(40 \mathrm{~cm})$. Thus, to estimate dry matter production over the experimental period, it was done an adjustment of the necessary days to the cuts according to the following method:

The experimental period considered was 154 days, obtained by the sum of the days that the control treatment took to reach the right moment to be cut in each one of the four cuts (cut $1=37$; cut $2=42$; cut $3=40$ and cut $4=35$ days). Dry matter production estimative (DME) in each cut (C) was determined by multiplying the respectively dry matter accumulation (DMA) of each treatment $(\mathrm{T})$ by the number of days for the cut: DME Control = DMA Control C1 × 37; DMA Control C2 $\times 42$; DMA Control C3 $\times 40$ and DMA Control C4 $\times 35$.

The total dry matter production estimate (TDME) over the experimental period was determined by the sum of dry matter production of the four cuts: TDME Control = DME Control C1 + DME Control C2 + DME Control C3 + DME Control C4.

The variables dry matter estimative (DME), total dry matter production estimative (TDME), crude protein (CP) and neutral detergent fiber (NDF) were submitted to the analysis of variance (ANOVA). The relationship among the independent variable (swine slurry levels) with the dependent variables was established by the regression analyses. Linear and quadratic models were evaluated for each variable. The output parameters were analyzed by the statistical program, Statigraphic 4.1. at a significance level of $5 \%$.

\section{Results and Discussion}

The numbers of days between the forage cuts at the $1^{\text {st }}$ and $2^{\text {nd }}$ application as well as the length of the experimental period were influenced by the swine slurry levels (Table 3 ). As the swine slurry level increased, the days between cuts were reduced, resulting in higher dry matter production, showed by the dry matter accumulation rate (Table 4).

However, this increase in dry matter production was not the same among the cuts. The increments were significant at the first cut after the swine slurry application (cuts 1 and 3), but they did not differ among the cuts subsequent to the application (cuts 2 and 4). This effect
Table 3 - Number of days to the first cut and between cuts of the Tifton 85 fertilized with different swine slurry levels in two applications

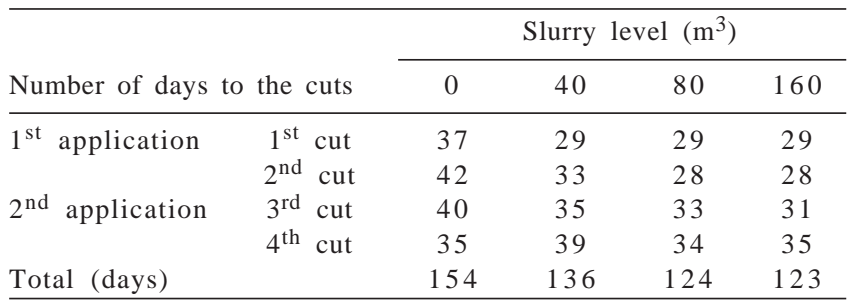

Table 4 - Dry matter accumulate rate by cut of Tifton 85 fertilized with different swine slurry levels in two applications

\begin{tabular}{lccccc}
\hline & & \multicolumn{4}{c}{ Slurry level $\left(\mathrm{m}^{3}\right)$} \\
\cline { 3 - 6 } \begin{tabular}{l} 
Dry matter accumulate rate \\
\cline { 3 - 6 }$(\mathrm{kg} / \mathrm{ha} /$ day $)$
\end{tabular} & 0 & 40 & 80 & 160 \\
\hline $1^{\text {st }}$ application & $1^{\text {st }}$ cut $(*)$ & 139.1 & 168.21 & 195.68 & 205.56 \\
& $2^{\text {nd }}$ cut (ns) & 120.17 & 138.32 & 135.86 & 136.44 \\
$2^{\text {nd }}$ application & $1^{\text {st }}$ cut (*) & 112.47 & 154.46 & 173.8 & 162.36 \\
& $2^{\text {nd }}$ cut (ns) & 98.03 & 96.32 & 104.01 & 102.08 \\
Mean $(*)$ & & 117.44 & 139.33 & 152.34 & 151.61 \\
\hline
\end{tabular}

$*$ = significantly at $5 \%$; ns = not significantly.

shows that the plant responded to the slurry application at the first period of pasture growing, not showing a residual effect to the subsequent cut.

The regression study of the dry matter production estimative (DME) shows, however, the respectively regression equation in each cut (Figure 2) in which that the most technical efficiency (MTE) to this variable was found with the slurry level of 143 and $106 \mathrm{~m}^{3} / \mathrm{ha}$, which was equivalent to 7.655 and $7.153 \mathrm{~kg}$ of $\mathrm{DM} /$ ha respectively for the $1^{\text {st }}$ and $3^{\text {rd }}$ cut.

The sum of the swine slurry application in its technical efficiency levels $\left(249 \mathrm{~m}^{3} / \mathrm{ha}\right.$ ) resulted in a total forage production of 24,260 kg of DM/ha (Figure 3).

The forage production at the technical efficiency levels was around $6,000 \mathrm{~kg}$ of $\mathrm{DM} / \mathrm{ha}$ higher than the treatment without swine slurry $(18,136 \mathrm{~kg}$ of DM/ha), showing that the use of swine slurry positively influenced the carrying capacity of the pasture inasmuch as it increases dry matter production per hectare.

Comparing the forage tissue crude protein and neutral detergent fiber content, it was noticed a significant interaction between slurry level and forage cuts. The regression study of the first cut shows that there was a quadratic response from the variables. For the crude protein variable, there was an increment in the plant tissue while the neutral detergent fiber decreased as slurry levels increased (Figure 4). 


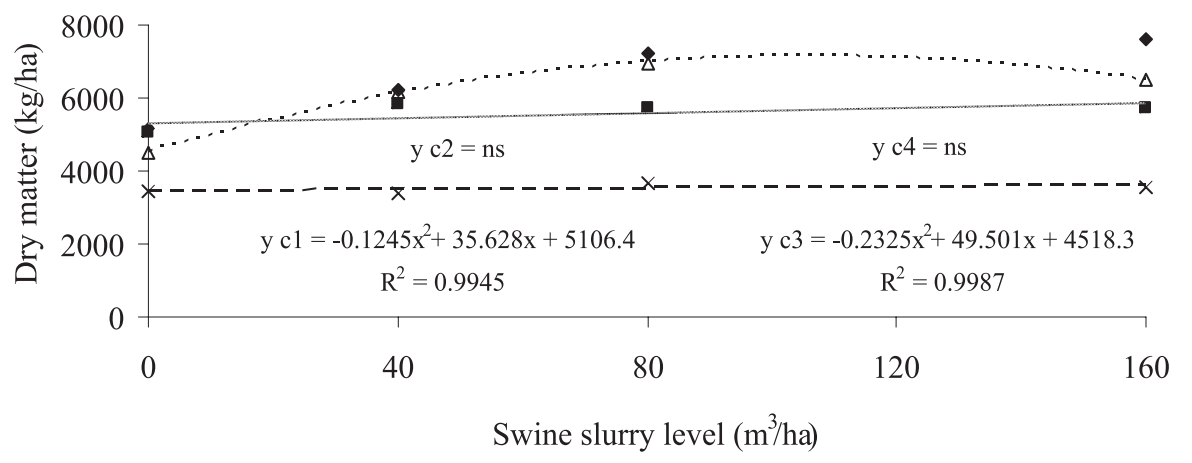

- corte $1 \cdots \cdots \cdot$ corte $3 \ldots$ corte $2----$ corte 4

Figure 2 - Estimative of the dry matter production at the cuts 1, 2, 3, and 4 in a Tifton 85 pasture fertilized with different swine slurry levels in two applications.

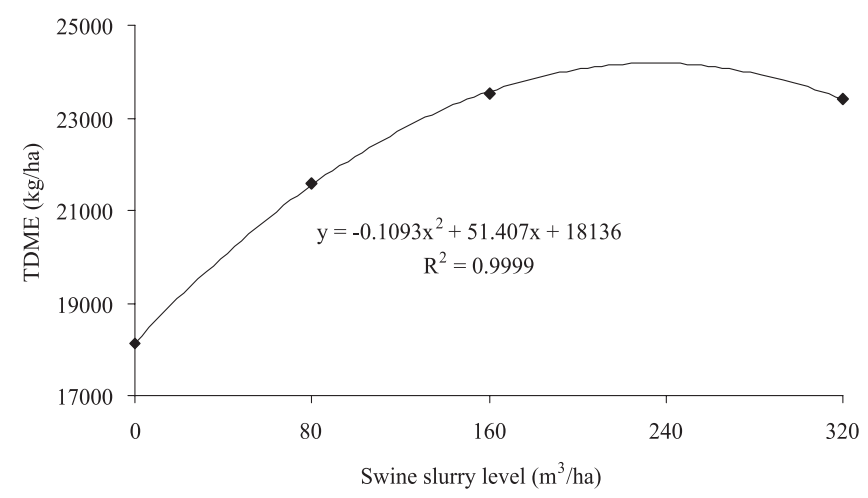

Figure 3 - Tifton 85 dry matter production along the experimental period fertilized with swine slurry levels split in two applications and submitted to four cuts.
By the crude protein and nutrient detergent fiber equations, the most technical efficiency was determined for each variable, in which the level 123 and $118 \mathrm{~m}^{3} /$ ha the most technical efficiency level respectively. These levels are equivalent to $18.42 \%$ of $\mathrm{CP}$ and $63.12 \%$ of NDF.

These results show that the nitrogen levels in the plant tissue increased in response to the nitrogen levels applied. It is also possible to observe in figure 4, that the increase of crude protein is associated with fiber reduction, represented by the neutral detergent fiber, showing the positive effect of the swine slurry levels on the forage nutritive value. The decrease in neutral detergent fiber can be associated, according to Rocha et al. (2002), to the
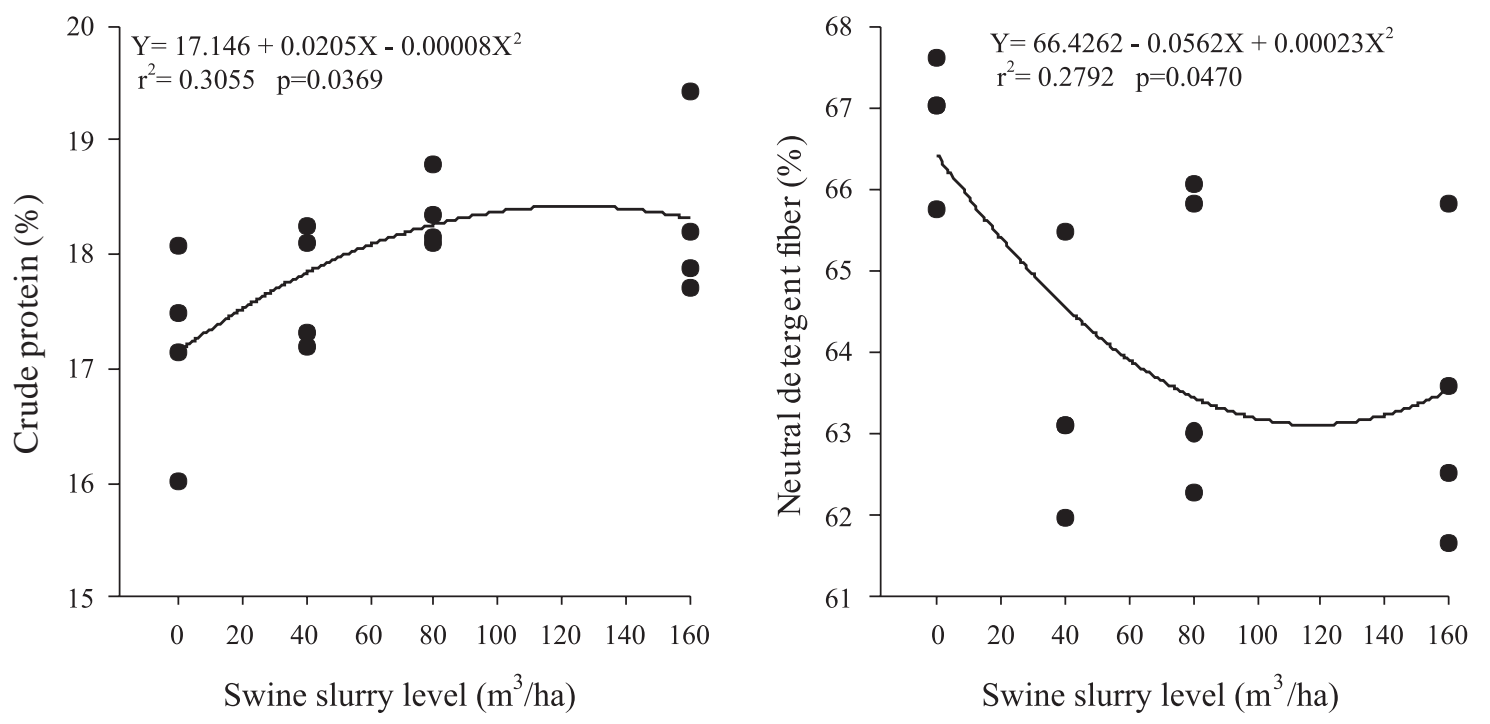

Figure 4 - Dry matter crude protein percentage and neutral detergent fiber at the Tifton 85 first cut fertilized under different levels of swine slurry. 
dilution effect inasmuch as the forage production was increased as the nitrogen levels were increased. According to these authors, this decrease is desirable, once the fiber reduction allows a better forage digestibility and a higher forage consume.

Crude protein increase with the increased nitrogen levels was also noticed by Menegatti et al. (2002) and Gonçalves et al. (2003), confirming that nitrogen has a positive effect on the dry matter production and on nitrogen tissue content in tropical grasses, in which the higher answers were obtained with nitrogen levels of 400 and $500 \mathrm{~kg}$ of N/ha.

Nitrogen influence changes according to the forage species, season of the year, time between cuts or grazing and the number of cuts, source of nutrients, plant fenologic stage and the soil fertility (Balsalobre et al. 2002), in which the efficiency of use was reduced as the $\mathrm{N}$ levels increase (Primavesi et al. 2001). The data from this experiment are in agreement with the statements cited by the prior authors, (Figure 3). Over the level $124 \mathrm{~m}^{3}$ of swine slurry (252 kg de N/ha), Tifton grass did not respond in terms of tissue nitrogen concentration.

When it was compared the technical efficiency level of the dry matter accumulation rate ( $143 \mathrm{~m}^{3}$ of slurry/ha) with the technical efficiency of the nitrogen ( $124 \mathrm{~m}^{3}$ of slurry/ha), it was observed that the curve decline occurred before nitrogen, suggesting that the plant continued producing dry matter without a proportional increase in the nitrogen concentration. This fact shows that the response by Tifton 85 to the slurry applied is not directly related with nitrogen, which means that other nutrients or other factors might be influencing the forage dry matter production or, the pasture nitrogen necessity is supplied by the level $124 \mathrm{~m}^{3}$ of slurry/ha, but the plant continuous to produce dry matter until the adequate supplement of other factors.

Recommendation found in literature on nitrogen levels, regardless to the used source, to produce dry matter and crude protein are higher than the values found in this experiment at the most technical efficiency (290 and $252 \mathrm{~kg}$ of ${\mathrm{N} . h a^{-1}}^{-}$respectively).

From the regression curves, it was possible to observe that, for all the variables (dry matter accumulation, total dry matter estimative, crude protein, neutral detergent fiber and nitrogen), there was one slurry level that exceeded the maximal Tifton 85 production at the first cut. Therefore, swine slurry can be recomended for Tifton 85 pasture fertilization, mainly if it was considered the rapid pasture response, in terms of DM production, just after slurry application.

According to the results by ANOVA analyses, crude protein and neutral detergent fiber behavior at the second cut was similar to the responsed obtained at the first cut. The slurry levels increment continued increasing the nitrogen tissue content and reducing the neutral detergent fiber in the second plant growing period (Figure 5).

It was noticed that the slurry levels did not promote a significant effect on dry matter production, however, the $\mathrm{N}$ content in the plant tissue increased in the second growing period, in which there was no slurry addition, showing that the nitrogen availability was adequate to the pasture necessity.

This result suggests that at the second cut, another factor which is not nitrogen, would be limiting the pasture to express its maximal growing potential, just as it was demonstrated for the first cut.
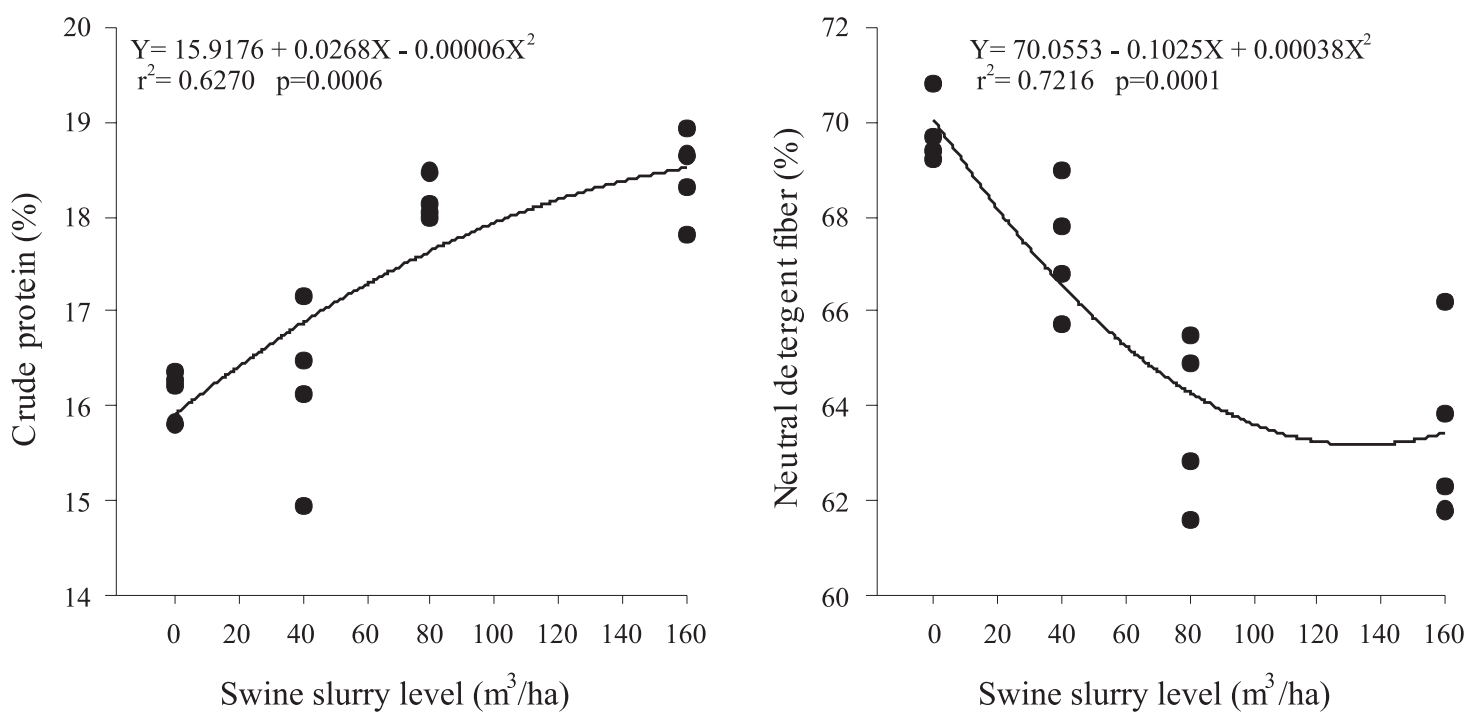

Figure 5 - Crude protein percentage and neutral detergent fiber of Tifton 85 fertilized with levels of swine slurry at the second cut. 
Crude protein increase and the neutral detergent fiber decrease related to the increment in slurry levels show that the proportion of the $\mathrm{N}$ in the dry matter increase related to the other components consequently increasing the forage nutritive value.

The study of the crude protein and NDF content at the third cut, after slurry reapplication, showed a similar behavior among the $1^{\text {st }}$ and $2^{\text {nd }}$ cut. Tifton 85 pasture linearly responded to the slurry levels, increasing the $\mathrm{CP}$ and reducing NDF as the slurry levels were increased (Figure 6).

The linear tendency of the third cut, compared to the quadratic tendency of the $1^{\text {st }}$ and $2^{\text {nd }}$ cuts demonstrate that the $\mathrm{N}$ availability was lower at this moment and because of this, the peak of the curve inflexion was not reached. This response might be associated with the lower slurry nutrient concentration at the second slurry application (Table 2).
At the fourth forage cut, similarly to the results found at the third cut, it was noticed that the increment in the slurry levels continued promoting, respectively, an increase in the contents of crude protein and a decrease in the contents of neutral detergent fiber in tissues of Tifton 85 (Figure 7).

Nitrogen efficiency of use ( $\mathrm{kg}$ of $\mathrm{DM} / \mathrm{kg}$ of $\mathrm{N}$ ) and nitrogen recovery (\%)decreased as the swine slurry levels were increased (Table 5). This behavior is similar to the data found by Menegatti et al. (2002); Rocha et al. (2002); and Primavesi et al. (2006), who worked with different nitrogen levels on pastures.

For Menegatti et al. (2002), this effect can be attributed to the Mitschelich law, which states that by adding increased levels of one nutrient, the highest production increment is obtained with the first level and with the use of higher levels, the production increment is lower each time proportionally.
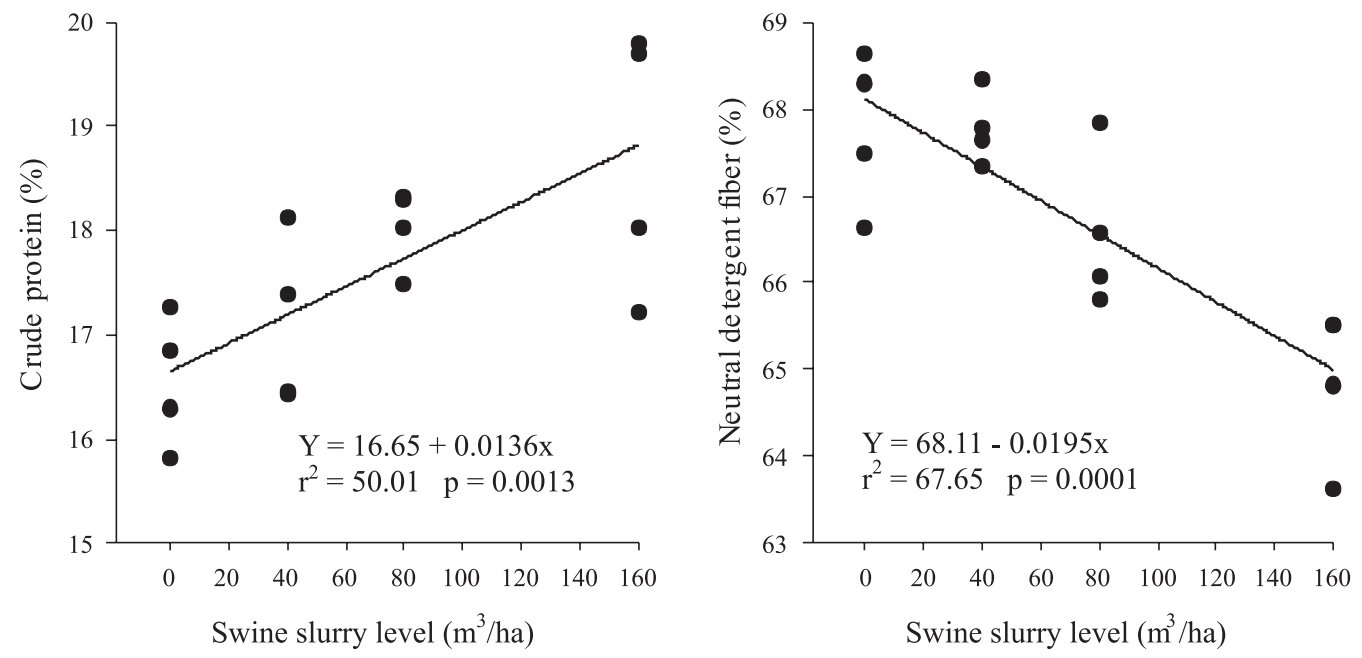

Figure 6 - Percentage of crude protein and neutral detergent fiber in Tifton 85 fertilized with levels of swine slurry at the $3^{\text {rd }}$ cut.
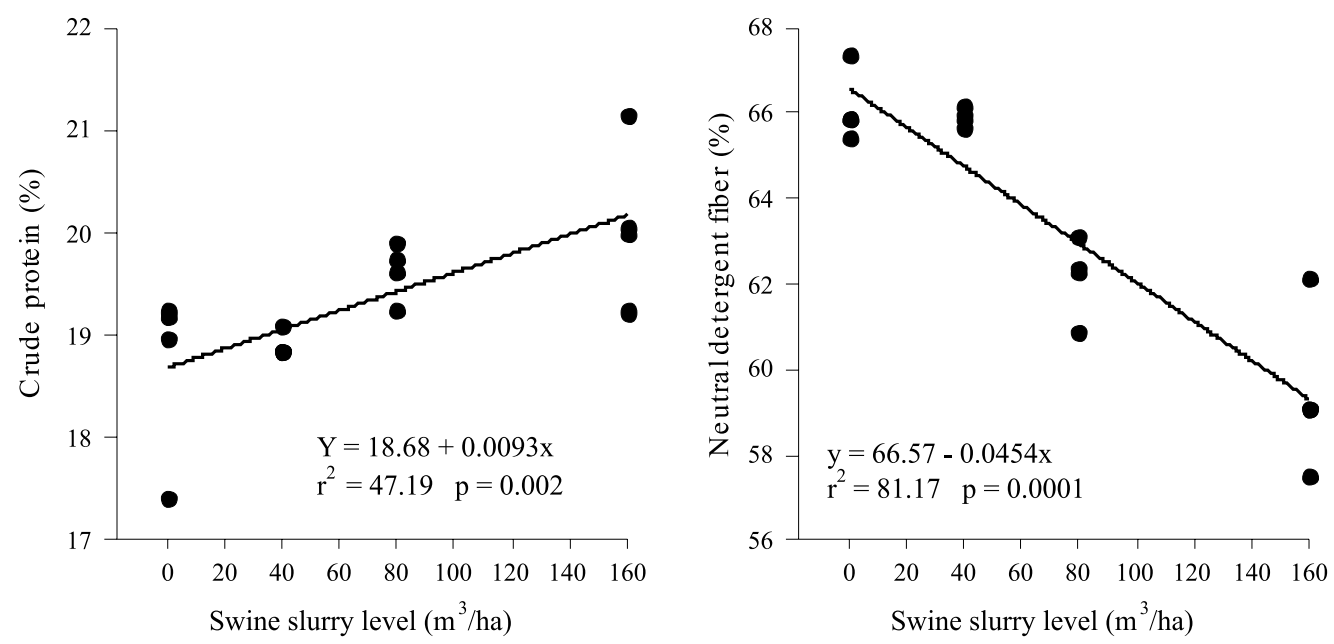

Figure 7 - Percentage of crude protein dry matter and neutral detergent fiber in Tifton 85 fertilized with levels of swine slurry at the fourth cut. 
Table 5 - Nitrogen use efficiency and nitrogen recovery in Tifton 85 fertilized with different levels of swine slurry

\begin{tabular}{lcccc}
\hline & \multicolumn{4}{c}{ Slurry level } \\
\cline { 2 - 5 } & 0 & 80 & 160 & 320 \\
\hline Applied nitrogen (kg/ha) & 0 & 144 & 288 & 576 \\
Dry matter (kg/ha) & 18,124 & 21,583 & 23,538 & 23,403 \\
Nitrogen use efficiceny & 0 & 24 & 19 & 9 \\
(kg DM/kg N) & & & & \\
Acum nitrogen (kg/ha) & 499 & 604 & 697 & 708 \\
Nitrogen recovery (\%) & 0 & 73 & 69 & 36 \\
\hline
\end{tabular}

The response from the plant to the $\mathrm{N}$, decreased as the $\mathrm{N}$ levels increased, probably because in high $\mathrm{N}$ level, lost is more likely to happen (Rocha et al., 2000; Menegatti et al., 2002; Scherer, 2002). It happens because plants have a certain capability to answer to the $\mathrm{N}$ present in the soil, capability that is involved with the genetic potential of the plant to absorb nitrogen (Dougherty \& Rhykerd, 1985). Another factor limiting the forage production could be the lack of other nutrients, such as P and K (Salette \& Huché, 1991).

Nitrogen recovery showed a behavior similar to nitrogen use efficiency, decreasing as the slurry levels were increased (Table 5). This fact means that the accumulation percentage of $\mathrm{N}$ in the plant was not proportional to the nitrogen levels increased by the increased slurry level.

This result can be associated with the proportional lower dry matter production related to the slurry increased levels, equal to the nitrogen use efficiency. Losses of nitrogen increase as the nitrogen levels increase and also the species capacity to absorb nitrogen is easily exceeded when high $\mathrm{N}$ levels are used (Seganfredo, 2000).

This behavior had already been noticed by Griffith et al. (1997), whose work reported that dry matter yield increment for each unit of available nutrient decreased as the yield got closer to the plant maximal production potential. According to the authors, it happens because losses are proportional to the level applied and beyond the lower nitrogen recovery and use efficiency, higher levels of slurry might bring up environmental problems, such as water pollution.

In general, the use of swine slurry as a fertilizer, allows a reduction in the production cost and it is also the best destination for this by-product. However, it is also important to emphasize that the most technical efficiency level might not be coincident with the most economical level.

Following this idea and considering that the most technical efficiency level of slurry was $249 \mathrm{~m}^{3}$ /ha, it was possible to calculate its total cost based on Kuns et al. (2005). According to it, slurry manure storage and appliance process, considering a trip of $4 \mathrm{~km}$ from the manure pit to the field and its return, cost R 183.99 for each $50 \mathrm{~m}^{3} /$ ha/year. Because the recommendation of this experiment was $249 \mathrm{~m}^{3} / \mathrm{ha}$, the total cost was $R \$ 916.00$ per hectare $\left(249 \mathrm{~m}^{3} / \mathrm{ha} / 50 \mathrm{~m}^{3} / \mathrm{ha}\right.$ $\times \mathrm{R} \$ 183.99$ ).

Furthermore, it is possible to observe that the swine slurry level $249 \mathrm{~m}^{3} / \mathrm{ha}$ is equivalent to $456 \mathrm{~kg} / \mathrm{ha}$ of $\mathrm{N}$; $327 \mathrm{~kg} / \mathrm{ha}$ of $\mathrm{P}_{2} \mathrm{O}_{5}$ and $278 \mathrm{~kg} / \mathrm{ha}$ of $\mathrm{K}_{2} \mathrm{O}$ (Table 1 ).

Using as a reference the research done by Chaves (2008), who shows a mean historic price (1979 to 2004) of $\mathrm{R} \$ 981.70$ per ton of nitrogen fertilizer, $\mathrm{R} \$ 542.00$ per ton of phosphorous and R\$860.30 per ton of potassium and considering the use of urea as a nitrogen source ( $45 \%$ of $N$ ), super triple as a phosphorous source $\left(42 \% \mathrm{P}_{2} \mathrm{O}_{5}\right)$ and KCL as a source of potassium $\left(60 \%\right.$ of $\left.\mathrm{K}_{2} \mathrm{O}\right)$, it was possible to estimate the cost of the chemical fertilization related to the slurry fertilizer.

To obtain $456 \mathrm{~kg}$ of $\mathrm{N}$, using urea as source, it is necessary to apply $1.013 \mathrm{~kg}$ of urea. Considering its historic price of $\mathrm{R} \$ 0.98$ per $\mathrm{kg}$ by the necessary quantity, there is a cost of R\$ 995.00 to the nitrogen fertilization. For phosphorous fertilization, $327 \mathrm{~kg}$ of $\mathrm{P}_{2} \mathrm{O}_{5}$ is equivalent to $778 \mathrm{~kg}$ of super triple. Considering its historic price of $\mathrm{R} \$ 0.54$ per kg by the necessary quantity, there is a cost of $\mathrm{R} \$ 422.00$ to the phosphorous fertilization. And the same can be calculated for potassium inasmuch as it is necessary $278 \mathrm{~kg}$ de $\mathrm{K}_{2} \mathrm{O}$, which is equivalent to $463 \mathrm{~kg}$ of KCL, which costs $\mathrm{R} \$ 0.86$ per $\mathrm{kg}$, there will be a cost of $\mathrm{R} \$ 398.00$.

Thus, by adding all the nutrients, the final cost for the chemical fertilization is $\mathrm{R} \$ 1,815.00$ which is $\mathrm{R} \$ 900.00$ more expensive than the slurry fertilizer. In this simulation, the cost of the chemical fertilizer distribution was not calculated, what would have increased this value.

This calculus shows that the fertilization cost of swine slurry is feasible when compared to the chemical fertilization as long as the trip distance is not very far. Another factor to be considered is the dry matter content of the slurry because the increase in the slurry dry matter content can reduce its storage and application costs.

Also, if it is considered that swine slurry is a by-product with a high environmental impact, using it as a fertilizer promote a correct destination to this by-product, besides the advantages of cost reduction, allowing the integration of different activities on the farm.

\section{Conclusions}

Swine slurry has a positive influence on Tifton 85 dry matter production, which makes it an option of fertilizer source to be used in pastures. The most technical efficiency 
is obtained with the addition of $235 \mathrm{~m}^{3} /$ ha of swine slurry, which is equivalent to 423, 302 e $258 \mathrm{~kg} / \mathrm{ha}$ de $\mathrm{N}, \mathrm{P}_{2} \mathrm{O}_{5}$ and $\mathrm{K}_{2} \mathrm{O}$, respectively. Swine slurry also increases pasture nutritive value by reducing neutral detergent fiber and increasing crude protein levels. Nitrogen recovery and use efficiency decreases as the slurry levels increase.

\section{References}

ADELI, A.; VARCO, J.J.; SISTANI, K.R. et al. Effects of swine lagoon effluent relative to commercial fertilizer applications on warm-season forage nutritive value. Agronomy Journal, v.97, p.408-417, 2005.

ALVIM, M.J.; XAVIER, D.F.; VERNEQUE, R.S. et al. Resposta do tifton 85 a doses de nitrogênio e intervalos de cortes. Pesquisa Agropecuária Brasileira, v.34, n.12, p.2345-2352, 1999.

ASSIS, F.O.; MURATORI, A.M. Poluição hídrica por dejetos de suínos: um estudo de caso na área rural do município de Quilombo, Santa Catarina. Revista Eletrônica Geografar, v.2, n.1, p.4259, 2007.

BALSALOBRE, M.A.A.; SANTOS, P.M.; BARROS, A.L.M. Inovacões tecnológicas, investimentos financeiros e gestão de sistema de producão animal em pastagens. In: SIMPÓSIO SOBRE MANEJO DE PASTAGEM, 2002, Piracicaba. Anais... Piracicaba: FEALQ, 2002. p.1-30.

BASSO, C.J.; CERETTA, C.A.; DURIGON, R. et al. Dejeto líquido de suínos: II - perdas de nitrogênio e fósforo por percolação no solo sob plantio direto. Ciência Rural, v.35. n.6, p.1305-1312, 2005.

CHAVES, M.L. [2008] Quando pensar na compra de insumos. Disponível em: <http://www.rehagro.com.br/siterehagro/ publicacao.do?cdnoticia=137> Acesso em: 10/6/2008.

DRUMOND, L.C.D.; ZANINI, J.R.; AGUIAR, A.P.A. et al. Produção de matéria seca em pastagem de tifton 85 irrigada, com diferentes doses de dejeto líquido de suíno. Engenharia Agrícola, v.26, n.2, p.426-433, 2006.

DOUGHERTY, C.T.; RHYKERD, C.L. The role of nitrogen in forage-animal production. In: HEATH, M.E.; BARNES, R.F.; METCALFE, D.S. (Eds.). Forages: the science of grassland agriculture. Ames: Iowa State University Press, 1985. p.318-325.

GONÇALVES, G.D.; SANTOS, G.T.; JOBIM, C.C. et al. Determinação do consumo, digestibilidade e frações protéicas e de carboidratos do feno de tifton 85 em diferentes idades de corte. Revista Brasileira de Zootecnia, v.32, n.4, p.804-813, 2003.

GRIFFITH, S.M.; OWEN, J.S.; HORWATH, W.R. Nitrogen movement and water quality at a poorly-drained agricultural and riparian site in the Pacific Northwest. Soil Science Plant Nutrition, v.43, p.1025-1030, 1997.

KONZEN, E.A. Manejo sustentável dos dejetos de suínos. [2007]. Disponível em: <http://www.pecnordeste.com.br/doc/ suinocultura/Eg\%C3\%ADdio\%20Arno\%20Konzen.pdf>. Acesso em: 27/11/2007.

KUNS, A.; CHIOQUETTA, O.; MIELE, M. et al. Comparativo de custos de implantação de diferentes tecnologias de armazenagem/ tratamento e distribuição de dejetos de suínos. Concórdia: Embrapa Suínos e Aves, 2005. 16p.
MARTEN, G.C.; SHENK, J.S.; BARTON, F.E. Near infrared reflectance spectroscopy (NIRS). Washington: USDA, 1985. 96p. (Agriculture Handbook, 643).

MENEGATTI, D.P.; ROCHA, G.P.; FURTINI NETO, A.E. et al. Nitrogênio na produção de matéria seca, teor e rendimento de proteína bruta de três gramíneas do gênero Cynodon. Ciência e Agrotecnologia, v.26, n.3, p.633-642, 2002.

MONTEIRO, D.O.; PINHEIRO, V.M.C.; MOURÃO, J.L.M. et al. Strategies for mitigation of nitrogen environmental impact from swine production. Revista Brasileira de Zootecnia, v.39, p.317-325, 2010 (supl. especial).

MENEZES, J.F.S.; ANDRADE, C.L.T.; ALVARENGA, R.C. et al. Utilização de resíduos orgânicos na agricultura. Disponível em: <http://www.planetaorganico.com.br/trabJune.htm>. Acesso em: 20/10/2007.

PEDREIRA, C.G.S.; NUSSIO, L.G.; SILVA, S.C. Condições edafoclimáticas para produção de Cynodon spp. In: SIMPÓSIO SOBRE MANEJO DE PASTAGEM, 2002, Piracicaba. Anais.. Piracicaba: FEALQ, 1998. 296p.

PELLEGRINI, L.G.; MONTEIRO, A.L.G.; NEWMAN, M. et al. Produção e qualidade de azevém-anual submetido a adubação nitrogenada sob pastejo por cordeiros. Revista Brasileira de Zootecnia, v.39, n.9, p.1894-1904, 2010.

PRIMAVESI, A.R.; FREITAS, A.C.P.; PRIMAVESI, A. Qualidade ambiental em sistemas intensivos de produção de bovinos de leite, na microbacia do Ribeirão Canchim: indicadores, manejo e problemas. São Carlos: Embrapa Pecuária Sudeste, 2001. 70p. (Boletim de Pesquisa, 7).

PRIMAVESI, O.; PRIMAVESI, A.C.; CORRÊA, L.A. et al. Lixiviação de nitrato em pastagem de coastcross adubada com nitrogênio. Revista Brasileira de Zootecnia, v.35, n.3, p.683-690, 2006.

ROCHA, G.P.; EVANGELISTA, A.R.; LIMA, J.A. Nitrogênio na produção de matéria seca, teor e rendimento de proteína bruta de gramíneas tropicais. Pasturas Tropicales, v.22, n.1, 2000.

ROCHA, G.P.; EVANGELISTA, A.R.; LIMA, J.A. et al. Adubação nitrogenada em gramíneas do gênero Cynodon. Ciência Animal Brasileira, v.3, n.1, p.1-9, 2002.

ROLIN, G.S.; SENTELHAS, P.C.; BARBIERI, V. Planilhas no ambiente Excel ${ }^{\mathrm{TM}}$ para os cálculos de balanços hídricos normal, seqüencial de cultura e de produtividade real e potencial. Revista Brasileira de Agrometeorologia, v.6, n.1, p.133-137, 1998.

SALETTE, J.; HUCHÉ, L. Diagnostic de I'état de nutrition minérale d'une prairie par analyse de v'gétal: príncipes, mise em ceuvre, exemples. Fourrages, n.125, p.3-18, 1991.

SCHERER, E.E. Aproveitamento do esterco de suínos como fertilizante. In: CURSO DE CAPACITAÇÃO EM PRÁTICAS AMBIENTAIS SUSTENTÁVEIS: treinamentos. Concórdia: Embrapa Suinos e Aves, 2002. p.91-101.

SCHERER, E.E.; AITA, C.; BALDISSERA, I.T. Avaliação da qualidade do esterco líquido de suínos da região Oeste Catarinense para fins de utilização como fertilizante. Florianópolis: EPAGRI, 1996. 46p.

SEGANFREDO, M.A. Análise dos riscos de poluição do ambiente, quando se usa dejetos de suínos como adubo do solo. Concórdia: Embrapa Suínos e Aves, 2000. p.1-3.

Tedesco, M.J.; GiAnello, C.; BARY, A.I. et al. Análise de solo, plantas e outros materiais. Porto Alegre: Universidade Federal do Rio Grande do Sul, 1995. 174p. 